\title{
The East Asian Industrial Policy Experiences: Implications for Vietnam
}

\author{
Hong Chuong Pham \\ National Economics University, Hanoi, Vietnam \\ Kenichi Ohno \\ Graduate Institute for Policy Research, Tokyo, Japan \\ Manh Dung Tran \\ National Economics University, Hanoi, Vietnam
}

\begin{abstract}
This paper offers an overview of East Asian industrial policies with special focus on small and medium enterprises (SME) development and linkage policy in an attempt to assess the relevance of their experiences for the contemporary Vietnam. At first, economic performance and policy quality of selected countries are reviewed. Following that, international policy comparison and key issues relevant to Vietnam's SMEs development and linkage policy are discussed and policy implications for Vietnam are made. Among them are capacity building with a reasonable scope and patience, scaling up by national ownership and selective industrial policy.
\end{abstract}

Keywords: Industrial policy, Small and medium enterprises, Linkage, Asia, Vietnam

DOI: $10.7176 / \mathrm{EJBM} / 11-33-08$

Publication date: November $30^{\text {th }} 2019$

\section{Introduction}

A number of East Asian countries like Japan, Taiwan, and Singapore are regarded as primary examples of countries that have derived great benefits from increasing integration with the international economy, without surrendering national autonomy in the economic or cultural spheres, by pursuing decidedly policies with respect to the industrial development (Noland and Howard, 2005). According to Ohno (2014), long-term income performance is correlated more strongly with the quality of industrial policy than country size, resource endowment, or the amount of official development assistance (ODA) or foreign direct investment (FDI). For instance, high-income economies such as Singapore and Taiwan boast high-quality industrial policies in both planning and execution. Upper middle-income economies such as Malaysia and Thailand have relatively good policies but there are certain pockets of weaknesses. Meanwhile, Indonesia, a lower middle income country, has many shortcomings in FDI, SMEs, linkage, technical and vocational education and training (TVET), supporting industry, industrial zone, and other industrial policy components which are continuously criticized by domestic and foreign investors. All these economies have been exerting industrialization effort for five to six decades already from very different initial conditions in terms of size, history, and resource endowment. We cannot say that small economies grow faster than large ones, or vice versa, or that national resources always accelerate industrialization. Indonesia has received large amounts of ODA and FDI but it has not succeeded as much as other economies in East Asia.

After the start of globalization in the early 1990s, Vietnam so far has spent only two decades in industrialization. But it already shows signs of policy weakness. The best way to approach a policy problem is to systematically review a number of countries that faced and solved (or did not solve) the same problem, then create a solution most suitable for Vietnam's local context based on the rich knowledge of international best and worst practices. While industrial policy covers many areas including the legal framework, infrastructure, finance, and green manufacturing, we believe that the core of industrial policy must be strengthening the capabilities of people and enterprises - in other words, promoting knowledge, skills, technology, productivity, and innovation. Unless domestic citizens and firms become dynamic and competitive, sustainable growth into high income cannot be realized even if there are other favorable conditions. Moreover, strengthening can be done in two ways in a country receiving a large volume of manufacturing FDI such as Vietnam. People and enterprises can be strengthened firstly by working with already competitive foreign firms and learning from them (indirect competition), and secondly by fostering dynamic and independent SMEs without a close partnership with FDI (direct competition). These two tracks are both valid, and they should be tried in parallel to upgrade the industrial capability of Vietnam. That is why our paper features SME and FDI-SME linkage policies. Linkage policy are needed for the first track, while SME policy has the double aim of improving domestic firms for global competitiveness as well as for generating sufficient capability to link effectively with FDI.

\section{Vietnam economic performance}

The Vietnamese economy grew rapidly at an average rate of $7.6 \%$ from $1991-2010$ and $6 \%$ during the period of 
2010-2018 (General Statistical Office, 2018). This growth has continued to date and it has greatly elevated Vietnam's international standing from its former placing in 1990 when the country was amongst the world's poorest with a GDP per capita of US\$95. Rapid economic growth has resulted in Vietnam transitioning to a lower middle-income country (as defined by the World Bank) with a per capita income of US\$1,010 in 2009 (World Bank, 2019). The country has made significant progress on human development indicators, particularly on education, health and living standards, as reflected in the steady increase of its human development index (HDI) over the last decade.

Vietnam's economic structure shifted significantly from agriculture to industry over the last two decades. According to the national account data (General Statistical Office, 2018), between 1990 and 2012, the share of GDP of primary industries fell from $38.7 \%$ to $19.7 \%$ while the share of secondary industries (including manufacturing, utilities and construction) rose from $22.7 \%$ to $38.6 \%$. The share of services also rose but more modestly from $38.6 \%$ to $41.7 \%$. On the export side, the General statistics office (GSO) data using standard international trade classification's (SITC) rough categorization show similar industrializing trends. During $1995-$ 2017 , the share of primary exports in total export fell sharply from $67.2 \%$ to $16.3 \%$ while the share of manufactured exports jumped from $32.8 \%$ to $83.6 \%$. From these statistics, it looks as though Vietnam has successfully transformed its economic structure from agro-centered one to industry-based one in the last two decades.

In Vietnam the main engine of transformation is foreign firms. Since global economic integration of the early 1990s, Vietnam has become an attractive destination of FDI. As of end 2017, FDI into Vietnam (cumulative registered capital) recorded US\$319.6 billion, of which $58.4 \%$ was manufacturing and processing industry followed by real estate business (16.7\%), accommodation and food service (3.8\%), and construction $(3.4 \%)$ (General Statistical Office, 2018). Vietnam's success in attracting FDI has had a positive impact on the country's economic performance. During the period of 2000-2017, contribution of FDI to GDP has followed an increasing trend from $13.3 \%$ in 2000 to $19.6 \%$ in 2017 . FDI makes a particularly important contribution to export revenue. In 2017 , export by the FDI sector was more than US $\$ 155$ billion, or $72 \%$ of the country's total export. There is a rising trend of FDI exports over the period of 1995-2017, which rose faster than the export of the domestic invested sector.

Regarding sectoral trade balances (export less import), the FDI sector is a net exporter while the domestic sector is a net importer in Vietnam. The remarkable increase in manufactured exports in the last two decades was driven mainly by the activities of FDI firms while the domestic sector persistently ran trade deficits which sometimes grew to a very high level. In 2017, the trade balance surplus was US\$2.9 billion, of which the domestic economic sector experienced a trade deficit of US\$25.8 billion, while the FDI sector gained the export surplus of US\$28.7 billion.

Vietnam's manufactured export is driven by Samsung, Canon, Intel, Fujitsu, and other foreign big names as well as domestic and foreign garment and footwear producers. All of them feature labor-intensive operation while Vietnam depends heavily on imports of industrial materials, industrial components and consumer products. This pattern of exporting labor-intensive products and importing more advanced industrial materials and products has not changed very much in the last two decades.

Tables 1 and 2, using World Bank data, illustrate where Vietnam stands among Asian countries. Vietnam's manufacturing value-added, at 15.3\% of GDP in 2017, is much lower than those of Thailand, Korea, Malaysia or Indonesia. By the East Asian standard there is much room for further development in Vietnamese manufacturing. Table 1. Manufacturing value-added of selected East Asian countries (\% of GDP)

\begin{tabular}{lcccccccc}
\hline Countries & $\mathbf{1 9 8 5}$ & $\mathbf{1 9 9 0}$ & $\mathbf{1 9 9 5}$ & $\mathbf{2 0 0 0}$ & $\mathbf{2 0 0 5}$ & $\mathbf{2 0 1 0}$ & $\mathbf{2 0 1 5}$ & $\mathbf{2 0 1 7}$ \\
\hline Vietnam & 20.51 & 12.26 & 14.99 & 18.45 & 18.82 & 12.95 & 13.69 & 15.33 \\
Thailand & 21.09 & 27.20 & 26.47 & 28.59 & 29.79 & 31.07 & 27.50 & 27.09 \\
Malaysia & 19.67 & 24.22 & 26.38 & 30.86 & 27.55 & 23.43 & 22.71 & 22.27 \\
Indonesia & 16.37 & 19.89 & 24.13 & 22.66 & 27.41 & 22.04 & 20.99 & 20.16 \\
Japan & - & - & 23.47 & 22.56 & 21.64 & 20.83 & 20.72 & - \\
Korea & 23.85 & 24.60 & 25.22 & 26.01 & 25.52 & 27.80 & 27.09 & 27.57 \\
\hline
\end{tabular}

Source: World Bank, World development indicators database (accessed in Feb., 2019)

Turning to the share of manufactured exports in total export, in Table 2, Vietnam's ratio rose from $42.7 \%$ in 2000 to $64.7 \%$ in 2010 and $83.2 \%$ in 2017 , thereby joining the second-tier group of Malaysia, Thailand. But this is still lower than the top group of Japan and Korea. These pictures indicate that, quantitatively, the current status of Vietnam's industrialization is still modest in comparison of high performing East Asian countries. 
Table 2. Manufactured exports of selected East Asian countries (\% of total export)

\begin{tabular}{lcccccccc}
\hline Countries & $\mathbf{1 9 8 5}$ & $\mathbf{1 9 9 0}$ & $\mathbf{1 9 9 5}$ & $\mathbf{2 0 0 0}$ & $\mathbf{2 0 0 5}$ & $\mathbf{2 0 1 0}$ & $\mathbf{2 0 1 5}$ & $\mathbf{2 0 1 7}$ \\
\hline Vietnam & - & - & - & 42.66 & 50.19 & 64.65 & - & 83.20 \\
Thailand & 38.11 & 63.13 & 73.10 & 75.37 & 76.80 & 75.33 & 77.79 & - \\
Malaysia & 27.17 & 53.78 & 74.71 & 80.43 & 74.66 & 67.20 & 66.93 & 67.99 \\
Indonesia & 13.04 & 35.45 & 50.61 & 57.12 & 47.18 & 37.50 & 44.66 & 43.64 \\
Japan & 96.34 & 95.90 & 95.19 & 93.88 & 91.97 & 89.00 & 88.03 & 88.10 \\
Korea & 91.31 & 93.52 & 93.32 & 90.75 & 90.92 & 88.97 & 89.65 & 89.45 \\
\hline
\end{tabular}

Source: World Bank, World development indicators database (accessed in Feb., 2019)

In summary, Vietnam's industrialization is more apparent than genuine because value creation by the domestic industrial sector is still small. We can point to three facts associated with this problem: (i) Vietnam's manufacturing performance in value-added and export is still modest by East Asian standards, (ii) the main agents of structural transformation and value creation are FDI firms rather than domestic, and (iii) manufactured exports depend heavily on imported inputs. These weaknesses may have been tolerable in the early 1990s when Vietnam just began to integrate with the global economy. But persistence of the same situation after two decades of industrialization effort is a problem for Vietnam as the lack of competitiveness on the part of Vietnamese enterprises may cause de-industrialization at a middle income level without achieving full industrialization.

\section{Economic performance and policy quality}

Virtually every country promotes industry, but results differ dramatically. Within East Asia, Singapore, Taiwan, Malaysia, Thailand and Indonesia started industrialization around the same time, about five or six decades ago, from similar income levels. They deployed similar policies such as import substitution, export promotion, FDI attraction, SME development, industrial zones, TVET, management training, technology transfer. They also received similar technical assistance from donors. But today, their income achievements are wide apart. High income achievers include Singapore (per capita income of US\$54,530 in 2017) and Taiwan (US\$24,318). Upper middle income achievers are Malaysia (US\$9,650) and Thailand (US\$5,950). Meanwhile, Indonesia (US\$3,540) achieved only lower middle income after more than a half century of industrialization. Differences among these five economies cannot be explained by the industrial policy menu or the timing of industrialization, which were more or less the same. It must be explained by the quality and implementation details of the policy measures.

The quality of industrial policy with a main focus on human and enterprise capacity building in selected East Asian economies based on the studies of Ohno (2014), Pham (2016) was shown in Table 3. It is appear that income level and policy quality not only vary significantly across countries, but they are also highly correlated. This does not rigorously prove, but at least informally suggest, that one main cause of divergent long-term economic performance is the quality of industrial policy. Without good policy, high income is difficult to obtain even if the country has many natural or geopolitical advantages.

Compared with the five economies cited above, Vietnam is a latecomer with only about two decades of industrialization and globalization experience instead of five or six decades. In 2017 Vietnam's per capita income was US\$2,160 placing itself near the bottom of the lower middle income group. Objectively speaking, the quality of Vietnam's industrial policy is lower than that of Malaysia or Thailand, and far inferior to that of Singapore or Taiwan. The quality of Vietnam's industrial policy is judged as "poor," in the same range as Indonesia. There are some aspects in which Vietnam excels over Indonesia, and vice versa. The Vietnamese government has developed supporting industries and industrial parks step by step, a policy area in which Indonesia has little experience. Meanwhile, in Indonesia, stakeholder discussion in drafting key policy documents is more systematized than Vietnam with long and substantive interactions among ministries and with businesses and academics. But on average the two countries are roughly equivalent in their inability to effectively design and implement industrial policy. 
Table 3. Income performance and industrial policy quality

\begin{tabular}{|c|c|c|c|c|c|c|c|c|c|c|c|}
\hline \multirow[b]{2}{*}{ Countries/Regions } & \multirow[b]{2}{*}{$\begin{array}{c}\begin{array}{c}\text { Per } \\
\text { capita }\end{array} \\
\text { income } \\
2017 \\
(\mathrm{WB}, \\
2019 \\
\text { US\$) }\end{array}$} & \multirow[b]{2}{*}{$\begin{array}{l}\text { Easy } \\
\text { doing } \\
\text { business } \\
\text { ranking } \\
\text { (WB, } \\
\text { 2018) }\end{array}$} & \multicolumn{8}{|c|}{$\begin{array}{c}\text { Industrial policy assessment } \\
\text { (industrial human resource \& enterprise } \\
\text { support) }\end{array}$} & \multirow[b]{2}{*}{ Notes } \\
\hline & & & סे & 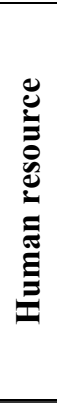 & 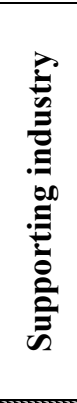 & 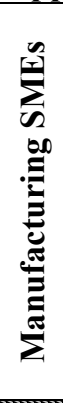 & 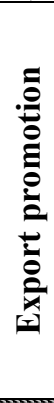 & $\frac{3}{\overline{0}}$ & & 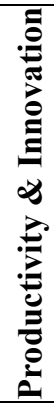 & \\
\hline Singapore & 54,530 & 2 & $\mathrm{~A}+$ & & & & & & & & $\begin{array}{l}\text { World's top } \\
\text { business location } \\
\text { since } 2007\end{array}$ \\
\hline Taiwan & $24,318^{*}$ & 15 & A & & N.A. & & & N.A. & & & $\begin{array}{l}\text { Reliable business } \\
\text { environment with } \\
\text { low corporate } \\
\text { income tax } \\
(17 \%) \text { No } \\
\text { investment } \\
\text { incentives except } \\
\text { for R\&D }\end{array}$ \\
\hline Malaysia & 9,650 & 24 & B & & & & & & & & $\begin{array}{lr}\text { Malaysian } & \\
\text { industrial } & \\
\text { development } & \\
\text { authority } & \\
\text { provides } & \text { good } \\
\text { services } & \text { and } \\
\text { supports } & \\
\end{array}$ \\
\hline Thailand & 5,950 & 26 & B- & & & & & & & & $\begin{array}{l}\text { Board } \\
\text { Investment } \\
\text { supports } \\
\text { investors well; } \\
\text { policies are } \\
\text { reasonably stable } \\
\text { \& predictable } \\
\end{array}$ \\
\hline Indonesia & 3,540 & 72 & $\mathrm{C}$ & & & & & & & & $\begin{array}{l}\text { Laws } \quad \& \\
\text { regulations are } \\
\text { unpredictable, } \\
\text { unclear \& } \\
\text { without proper } \\
\text { stakeholders } \\
\text { consultation } \\
\end{array}$ \\
\hline Vietnam & 2,160 & 68 & $\mathrm{C}$ & & & & & & & & $\begin{array}{l}\text { Improving slowly } \\
\text { since mid 1990s } \\
\text { but irregularities } \\
\text { still abound }\end{array}$ \\
\hline
\end{tabular}

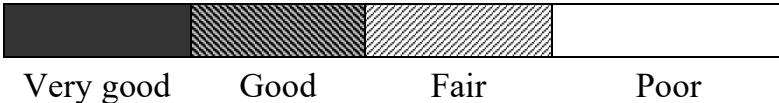

Note: Policy assessment excludes results of external factors, private effort or foreign support. *Taiwan's income data is from IMF. Taiwan no longer relies on FDI or FDI-based supporting industries. 


\begin{tabular}{|c|c|c|c|}
\hline Countries & FDI policy & $\begin{array}{l}\text { Manufacturing SME } \\
\text { promotion \& linkage }\end{array}$ & Industrial zones \\
\hline Singapore & $\begin{array}{l}\text { Highly strategic based } \\
\text { on individual deals }\end{array}$ & $\begin{array}{l}\text { Productivity support for } \\
\text { targeted segments }\end{array}$ & $\begin{array}{l}\text { State-owned \& strategic: overseas } \\
\text { expansion }\end{array}$ \\
\hline Taiwan & $\begin{array}{l}\text { (No longer important: } \\
\text { outward bound) }\end{array}$ & $\begin{array}{l}\text { Highly developed and } \\
\text { effective }\end{array}$ & $\begin{array}{l}\text { World model state-owned science- } \\
\text { parks \& EPZs }\end{array}$ \\
\hline Malaysia & High-tech orientation & $\begin{array}{l}\text { Well-coordinated by results } \\
\text { to be seen }\end{array}$ & Reasonably good \\
\hline Thailand & $\begin{array}{l}\text { Shifting to high-tech } \\
\text { orientation }\end{array}$ & $\begin{array}{l}\text { Generally weak except auto } \\
\text { part suppliers }\end{array}$ & $\begin{array}{l}\text { Many private IZs (AMATA \& } \\
\text { others): modest state-management }\end{array}$ \\
\hline Indonesia & $\begin{array}{l}\text { Restrictive \& } \\
\text { unfriendly: nationalistic }\end{array}$ & $\begin{array}{l}\text { Many scattered policies but } \\
\text { ineffective: clusters }\end{array}$ & Left to private sector \\
\hline Vietnam & $\begin{array}{l}\text { Irregular though slowly } \\
\text { improving }\end{array}$ & $\begin{array}{l}\text { Almost none despite } \\
\text { JICA/Jetro support }\end{array}$ & $\begin{array}{l}\text { Many state, provincial and private } \\
\text { IZs but many are plan only }\end{array}$ \\
\hline
\end{tabular}

Source: Adapted from Ohno (2014), Pham (2016) and authors' assessment

The above argument points to the critical importance of improving the quality of industrial policy with high attention on human and enterprise capacity building. This should be the core concern in formulating Vietnam's industrial policy. In this and the following sessions we highlight SME policy and FDI-local firm linkage policy (or linkage policy for short), which are the two key components of national capacity building.

\section{Small and medium enterprise development and linkage policy}

\subsection{Small and medium enterprise policy}

Development of SMEs is a very popular policy around the globe but its content and performance differ greatly across countries. Required policy components are diverse but well known-legal and policy framework, education and training, labor recruitment and relations, management and technology support, finance, FDI attraction and linkage, export, marketing, networking, industrial clusters, ITC, start-up and incubation, R\&D, innovation, women entrepreneurs, rental factories, one stop services, environmental responsibility etc. The success of SME policy depends on whether the country can plan, coordinate and implement a large number of mutually enhancing policy actions belonging to different ministries. Many governments produce little result because they lack the capability to conduct a large number of policy components simultaneously and interactively.

SME promotion has two distinct and separable purposes. The one is generation of income and job opportunities for the general population (poverty reduction) and the other is selective creation of excellent SMEs to become the creators of value and innovation (competitiveness). Both objectives are worthy and can be pursued in parallel if necessary, but the goals, strategies, and instruments they require are significantly different. For poverty reduction, SMEs in all size and sectors should be supported with simple procedure and few conditions for eligibility. Entry restriction and protection of certain sectors is also justified for shielding weak domestic SMEs against competitive pressure from foreign firms. For competitiveness, by contrast, selection criteria, screening and monitoring are essential and only those domestic enterprises that demonstrate sufficient upward mobility should be promoted. After the support is completed, they should be able to compete in an open business environment without protection. As a country moves from low income to middle and high income, SME policy focus usually shifts from poverty reduction to competitiveness. In high performing economies in East Asia, creation of competitiveness is the primary purpose of SME policy.

In Japan where both large enterprises and SMEs are well developed, the purpose of SME policy in the post WW2 period shifted gradually from the protection of SMEs against exploitation by large parent firms to the encouragement of innovation by SMEs as a source of Japan's global competitiveness. Japanese policy instruments and mechanisms for SME promotion are highly complex and advanced, combining public-private partnership, participatory policy making through "deliberation councils," technical assistance, financial support, repeated consultation, and so on. Probably this model is too difficult for most developing countries to adopt initially.

In Malaysia and Thailand, where the economy is highly industrialized but still dominated by foreign MNCs in electronics, automobile, and other machinery industries, the main policy goal is to increase internal value and replace foreigners with local managers, engineers, and designers. SME promotion is at the core of this strategy together with R\&D, science and technology, education and training, technology transfer, national branding, etc (VDF, 2006). In particular, Malaysia elevates SME policy as one of the key instruments of the New Economic Model for overcoming the middle income trap. Its formulation and execution are directed by the National SME Development Council, chaired by the prime minister and coordinated by SME Corporation Malaysia (SME Corp.), which harmonizes SME-related activities of fifteen ministries and 60 government agencies. SME Corp. under the Ministry of International Trade and Industry also acts as a one-stop service agency for SMEs.

Vietnam should also clearly define the objective for SME promotion and design policy instruments and 
mechanisms accordingly. It will be advisable for Vietnam to take the two-track approach whereby carefully selected manufacturing SMEs and supporting industry SMEs are strengthened for international competitiveness on the one hand, while broader and more general support is made available for all SMEs in manufacturing, trade and services on the other.

\subsection{Linkage policy}

Establishment of production linkage and networking, including subcontracting relations, with MNCs operating in the home country is an attractive strategic option for manufacturing SMEs in developing countries. Trade and investment liberalization as well as rapid diffusion of ICT have generated a global business environment in which MNCs can outsource not just basic inputs and processes but also high-value activities and sophisticated technologies from virtually anywhere in the world. For manufacturing SMEs, working with MNCs will provide a short-cut access to global management, improved standards, quality control, technology and finance which were previously unavailable due to various cross-border barriers and constraints. Another benefit is receipt of large and regular orders from anchor companies. Networking with MNCs may also lead to foreign market access as well as information on business procedure and distribution channels overseas.

However, the presence of MNCs does not automatically benefit SMEs. MNCs invest in developing countries in order to expand their business and make profit, not primarily to teach and improve local industries out of altruism. They may choose to outsource intermediate inputs and industrial services from their global supply chains abroad rather than from local suppliers with low quality and little global experience. Moreover, MNCs with superior business capabilities may out-compete and crowd out local companies. In this sense, arrival of a large number of manufacturing FDI firms is a double-edged sword. They may exert a negative competition effect which may be greater than a positive collaboration effect. Thus, local procurement and technology transfer do not happen naturally. To make MNCs truly work for national development, proactive policies by the government and hard work by local companies are needed.

Government policies in particular play an important role in enhancing linkages and positive spillovers. On the one hand, forcing the use of local inputs or technology transfer is often counterproductive in a world where countries compete fiercely to attract FDI, as global firms looking for the best production location will avoid countries with too many restrictions. Moreover, local content requirement clearly violates the WTO rule. On the other hand, simply liberalizing investment and providing generous incentives to FDI will not necessary expand networking and linkage opportunities with MNCs. Encouraging FDI-local firm linkage while avoiding its harmful consequences is a difficult assignment for governments with low policy capability. Linkage policy must be crafted with great care and subtleness under a good understanding of what foreign and domestic firms want.

Malaysia in the past made much effort to foster local component suppliers and strengthen their productive cooperation with MNCs and government linked companies (GLCs). The principal programs for this purpose were the Vendor Development Program (VDP) introduced in 1988 and the Industrial Linage Program (ILP) introduced in 1995-96. VDP was initiated as a program to support Bumiputra (local Malay) supplier firms to Proton, a stateowned national car company. Proton was obliged to buy as many components as possible from Malay firms, provide technical assistance to them, and help them obtain government loans. Later the scope of VDP was expanded to include electronics, furniture, construction materials and shipbuilding. Meanwhile, ILP was introduced as a policy instrument of the Small and Medium Industries Development Corporation (SMIDEC) established in 1996. It offered financial incentives, business matching and a multiple support package to small and medium industries (SMIs) in targeted sectors.

Supporting industry promotion and FDI-local firm linkage support under VDP and ILP were active in the 1980s and 90s. However, Malaysia subsequently dropped this policy without attaining strong supporting industries or industrial linkage. Malaysia's SME policy has veered away from linkage creation and is currently focused on the promotion of independent and innovative local SMEs without linkage with MNCs or GLCs.

In Thailand, by contrast, strengthening supporting industry SMEs continues to be a central pillar of industrial policy even today. For promoting FDI-local firm linkage, services rendered by the Board of Investment (BOI) Unit for Industrial Linkage Development (BUILD), established in 1992 within BOI, are particularly noteworthy. BUILD offers market-oriented support and matching services without providing tax privileges or other financial incentives. One of BUILD's most successful schemes has been the Vendors Meet Customers Program in which meetings and factory visits for registered suppliers and assemblers are organized to facilitate business matchmaking, especially in the automotive and electronics sectors. BUILD is also responsible for (i) operation of the ASEAN Supporting Industry Database which helps to build linkages with other ASEAN countries as well as the global market; (ii) annual Subcontracting Exhibition ("SUBCON Thailand"); and (iii) subsidies for local suppliers that market their products abroad. However, one weakness of BUILD, despite its good reputation, is the limited staff and budget which prevents expansion of its activities for greater impact.

There are also many non-official supplier development programs in Thailand. For example, the Thailand Automotive Institute (TAI) and the Electrical and Electronics Institute (EEI), both starting operation in 1999 as 
non-profit sectoral institutes under MOI, provide testing, information, consultation and training services to producers. They also coordinate with related official and non-official agencies and international partners to create new industrial programs.

Thus, Malaysia and Thailand did make effort in the past to strengthen FDI-local firm linkage as one component of supporting industry promotion. However, Malaysia's effort was terminated before it produced any significant results. Meanwhile, Thai effort is continuing and even producing some good results, but impact could have been greater if more resources were mobilized and greater policy attention was paid.

In advanced economies such as Japan, Taiwan and Singapore, linkage policy is no longer a key component of industrial policy because business networking is the responsibility of private firms which are now sufficiently global and competitive. These governments still organize such general standardized events as trade fairs and business seminars to help SMEs to meet new customers. Beyond that, however, no specific subsidies and measures are offered to the learning of advanced knowledge from foreign firms. Large firms in these economies no longer need such support; in fact, they more often play the role of teachers who teach skills and technology to local suppliers in other countries.

In the mean time, lower middle income countries such as Indonesia and Vietnam have not initiated any visible or effective official linkage programs (beyond normal trade fairs and business seminars) despite a great need for such programs. Almost all linkage programs in these countries are private sector- or donor-driven.

Our contention that, in pursuing the 2020 industrialization vision and beyond, Vietnam should follow the Thai way of working closely with FDI rather than the Malaysian way of disregarding it. This is because the former allows more time to improve domestic competitiveness than the latter in the age of global and regional integration. Without trade protection, domestic firms facing global competition without partnership with FDI will fail immediately if their competitiveness is insufficient; whereas FDI-linked technology transfer permits building local capability step-by-step even under free trade.

\section{Policy learning by comparing international best practices: Lessons learnt for Vietnam}

To acquire pragmatic policy capability to accelerate industrialization, international comparison of best policy practices is highly advisable. Improving policy quality is hardly possible if one examines Vietnam's own past and present only. One should look to the world for examples and models, and especially East Asia where instructive policy cases abound. Moreover, policy learning must be systematic and scientific rather than casual and random. Learning from foreign experiences should not mean copying policies adopted in some East Asian country at some point in time to Vietnam without considering the Vietnamese local context. The same can be said about learning from the West or any other region or country. Random copying rarely works because the situation each country faces is different. On the other hand, studying global and regional policy experiences should not lead to the rejection of foreign models as irrelevant because "our country is unique" (there are very few countries where this statement is not made). Both attitudes shut out the country from the possibility of policy improvement.

Many countries have succeeded in catch-up industrialization fully or partially. Each country tried in its own way, and paths to development are certainly diverse. But on close inspection, there are common factors for success even in this diversity. The purpose of gathering best policy practices from around the world is to foster general capacity to create an appropriate policy package using foreign models as raw materials, rather than copying them directly and uncritically. With full knowledge of the situation and constraints that Vietnam faces, the government must select, adjust, combine or simplify various foreign policy components to create a policy package most suitable for the Vietnamese context.

\subsection{Capacity building with a reasonable scope and patience}

At this point we would like to re-emphasize a few points raised earlier. Building up the capacity of domestic enterprises in a latecomer economy will normally take a long time, and policy must be designed and executed in steady and realistic steps rather than randomly implementing mutually unrelated short-term projects. The scope of SME policy can be highly country-specific and potentially very broad, ranging from rudimentary to highly advanced. In the early stage of industrialization, relatively simple SME policy that matches existing policy capability must be adopted.

In Japan, where SME policy is well developed, a large number of central and local supporting organizations provide assistance which are neatly summarized in The Guidebook for Using SME Measures published and revised by the SME Agency annually. As indicated in 2018 White Paper on Small and Medium Enterprises in Japan, SME policies implemented in fiscal 2017 in Japan were grouped into: (i) Initiatives to strengthen management and increase productivity; (ii) Increasing the numbers of vibrant leaders; (iii) Development of a stable business environment; (iv) Post-disaster restoration and reconstruction; (v) Initiatives by industries and area; (vi) Other SME policies including Environmental and energy measures, intellectual property, promotion of standardization and promotion of surveys and public information activities. These measures were built up over the several decades since the establishment of the SME Agency in 1948. For many developing countries, the Japanese model is too 
complex and difficult to adopt. They should start with a few selected measures, implement them, and gain experience before moving to more ambitious support measures.

One of the advanced support measures is handholding (also called hands-on or yorisoi support). It is a comprehensive SME support for carefully selected firms that show will and potentiality. More specifically, handholding must satisfy all following conditions: (i) Public (non-commercial) support where no or little fee is charged; (ii) One clear business goal is pre-set for each program, such as product development, creation of an industrial cluster, reaching a new export market, or overseas investment; (iii) A screening mechanism to select a small number of eligible firms; (iv) Duration of 2-3 years (usually non-renewable); (v) Customized multiple help is offered to each firm based on diagnosis and consultation and (vi) A high success rate is expected.

Handholding combines many existing policy components. It is practiced in a number of high-income economies including JETRO's assistance for SME export and overseas investment (Japan); KOTRA's support for SME export (Korea); SME Administration's support for creating local industrial clusters (Taiwan); and MATRADE's support for SME export (Malaysia). Handholding is not possible unless local government officials regularly visit SMEs and know their situations and needs well, basic functions such as kaizen, shindan, export promotion, and overseas market database already exist (so no new functions need to be added), and a large pool of experts in management, technology, marketing, finance, ICT, overseas business, innovation, etc. is available. The point is that successful handholding requires a sufficient number of good instructors and competent organizations already in place. For countries that do not have these conditions, including Vietnam, basic tasks such as training domestic experts and establishing minimum institutions should be the first thing to do before attempting handholding.

\subsection{Scaling up by national ownership}

One standard way of introducing a new policy is scaling up of a pilot project. Whether it is kaizen, TVET, FDI marketing or FDI-local firm linkage, a model is often created with international assistance. In Vietnam, for example, Japan International Cooperation Agency (JICA) has such industrial projects as (i) diagnostic and advisory services for Vietnamese supporting industry firms, (ii) curriculum and student matching between the Hanoi University of Industry and Japanese FDI firms, (iii) support for die and mold firms; and (iv) assistance in inviting Japanese manufacturing SMEs to some provinces. These projects are usually implemented by dispatched Japanese experts. While most of these projects produce good results at selected sites, the impact is still small relative to the large needs at the national level. However, a donor's budget is limited and cannot be expected to cover the entire nation. International cooperation should therefore be regarded as establishment of a pilot project to be copied geographically and across sectors to entire Vietnam. This scaling up should properly be the responsibility of the Vietnamese government mobilizing its officials and institutions. Sufficient national budget must also be committed for this purpose. The idea that donors provide models and the host country expands them nationwide is a well-accepted formula in many developing regions including Africa. Developing country governments should not expect donors to do the scaling up.

A related issue is the importance of training of trainers (TOT). It is a common practice among industrial donors, such as Japan and Germany, that foreign experts not only teach local firms but also coach domestic experts so they can teach firms after foreign experts leave. This is usually done by foreign and domestic experts visiting firms together. Initially, locals observe how foreign experts teach. Then they themselves teach while foreigners watch. Finally, local experts should be able to teach without foreign supervision. TOT is necessary for accelerating industrialization because the number of foreign experts available in any one developing country is limited. For instance, the main purpose of JICA's kaizen project phase II in Ethiopia (2011-2014) is to produce a sufficient number (about 400) of qualified Ethiopian kaizen experts who can replace JICA experts and disseminate kaizen activities nationwide. At this moment, there is no industrial project in Vietnam which aims at the creation of a large number of Vietnamese experts with official certification. All industrial projects should contain a TOT component from the beginning so that acquired knowledge will be expanded and continue to be used after the project comes to an end.

\subsection{Selective industrial policy}

This is a policy effort to promote a few to several targeted sectors rather than promoting all sectors and firms equally and indiscriminately. There is still a debate over whether such a policy is desirable or possible, but most East Asian governments have long accepted and practiced it as not only desirable but necessary policy for industrialization in the age of globalization. Some economists, including former World Bank chief economists Stiglitz and Lin, also strongly support selective intervention (Chang, 2002, Rodrik, 2007, Cimoli et al., 2009, Lin and Chang, 2009, Lin, 2010). From the East Asian perspective, the key point is not whether such a policy is desirable or not but which country can implement it most effectively to beat other regional rivals. We also take it for granted that Vietnam is weak in selective industrial policy and desperately needs to learn how to work closely with the private sector to do this. Policy capability can be learned only by actual doing and not just by academic 
debate or globally common advice. Promotion of a few targeted sectors will provide a practical ground on which government can try and improve policy measures.

In short, this paper analyzed the East Asian industrial policy with special focus on small and medium enterprises development and linkage policy in an attempt to assess the relevance of their experiences for the contemporary Vietnam.

It is clear that countries have different approaches to SME and linkage promotion although the general menu is fairly common. This considerations underscores the fundamental message of the East Asian experience: Learning from foreign experiences should be selective rather than "picking winner" strategies without considering the local context. After studying how each country conducts SME and linkage policy and knowing strengths and weaknesses of each, it is essential for Vietnam to identify a proper policy mix most suitable for Vietnam's circumstances. Vietnam's SME and linkage policies should be focused and not be too ambitious in terms of both scope and speed. It is far better to do a small number of policies competently and in pursuit of concrete objectives than introduce a large number of policies haphazardly. Many developing country governments say, "We are in a hurry, we cannot wait for a long time to adopt a policy". But adopting many policies without sufficient preparation is the main reason why such countries make little progress in industrialization.

\section{Acknowledgement}

This paper is a part of a major study on economic linkage between Japan and Vietnam under the context of globalization and regional economic integration, which was fully financed by the Government of Vietnam (project file KX.01.13/16-20). The authors are very grateful for this sponsorship.

\section{References}

Chang, H.J. (2002). Kicking away the ladder: development strategy in historical perspective, Anthem World History, London: Anthem Press.

Cimoli, M., Dosi, G. \& Stiglitz, J.E. (2009). Industrial policy and development, The political economy of capabilities accumulation, New York: Oxford University Press.

General Statistical Office (2018). Statistical year book of Vietnam 2017, Statistical publishing house, Hanoi, Vietnam.

Kuchiki, A. (2007). Industrial policy in Asia, IDE-JETRO Discussion Papers No. 128, Institute of Developing Economies, JETRO, Japan.

Lin, J.Y. (2010). New structural economics: A Framework for rethinking development. World Bank policy research working paper 5197, February.

Lin, J. \& Ha-Joon, C. (2009). Should industrial policy in developing countries conform to comparative advantage or defy it? A debate between Justin Lin and Ha-Joon Chang. Development Policy Review, 27(5), 483-502.

Noland, M. \& Howard, P. (2005). The east Asian industrial policy experience: Implications for the Middle East. Washington: Institute for International Economics.

Ohno, K. (2009). "Avoiding the middle income trap: Renovating industrial policy formulation in Vietnam," ASEAN Economic Bulletin, 26(1), 25-43.

Ohno, K. (2013). Learning to industrialize: From given growth to policy-aided value creation, Routledge.

Ohno, K. (2014). An approaching middle income trap: How Vietnam can escape it. Vietnam Development Forum. National Economics University, Vietnam Education publishing house, Hanoi, Vietnam.

Pham, H.C. (2016). Industrial policy of Japan opportunities for industrial development of Vietnam. Social labor publishing house, Hanoi, Vietnam.

Rodrik, D. (2007), Normalizing Industrial Policy, Cambridge, MA: Harvard University.

Vietnam Development Forum (2006). Industrial policy formulation in Thailand, Malaysia and Japan: Lessons learned for Vietnamese policy makers, Social labor publishing house, Hanoi, Vietnam.

Vietnam Development Forum (2013). A comparative study on foreign direct investment policy in selected ASEAN countries, research report.

World Bank (2019), GNI per capita, Atlas method (current US\$), https://data.worldbank.org/indicator/NY.GNP.PCAP.CD accessed September, 2019. 